\title{
Betty Friedan and Simone de Beauvoir
}

\author{
Charles Lemert
}

Betty Friedan died February 4, 2006 on her eighty-fifth birthday. Her passing marks the ending of an era of feminist revolution she helped to spark. Some would say that in America she started it all by herself. Certainly, The Feminine Mystique in 1963 fueled the fire of a civil rights movement that was about to burn out after a decade of brilliant successes in the American South. The rights in question for Friedan were, of course, those of womenmore exactly, as it turned out, mostly white women of the middle classes.

Unlike other movement leaders of that day, Friedan was a founder and first president of an enduring, still effective, woman's rights organization. NOW, (the National Organization for Women), came into being in 1966, but soon after was eclipsed by the then rapidly emerging radical movements. Many younger feminists found NOW's emphasis on political and economic rights too tame for the radical spirit of the moment. The late 1960s were a time for the Weather Underground, the SCUM Manifesto, Black Power and the Black Panthers. By 1968 even SDS was overrun by the radicalizing wave across the spectrum of social movements.

Yet, in time, Friedan's political and intellectual interventions proved the more lasting. SDS and SNCC are today subjects of historical study by academic sociologists who never came close to having their skulls crushed by a madman. But NOW survives in the work of many thousands in every state of the American Union. Early in the 2000s, by the measure of what now passes for left-liberal politics in America, NOW sounds downright progressive. NOW's 2006 statement of purpose remains true to Friedan's politics without the least trace of neo-liberal or thirdway drivel:

\footnotetext{
Since its founding in 1966, NOW's goal has been to take action to bring about equality for all women. NOW works to eliminate discrimination and harassment in the workplace, schools, the justice system, and all other sectors of society; secure abortion, birth control and reproductive rights for all women; end all forms of violence against women; eradicate racism, sexism and homophobia; and promote equality and justice in our society.
}

On the other hand, Feminine Mystique, the book that inspired it all, is remembered mostly for its historical importance. Yet, it is today an unread classic a half-century after it broke the code of silence that oppressed so many white women in their silly little suburban lives — uncomfortable in those vapidly comfortable houses. My mother was among those who did not read Friedan-so oppressed was she by a tyrannical and insecure husband. Yet, millions recognized the problem that, until Friedan, had no name. The flash of recognition that the modern way of family values was no more than a cheap and foul abuse of women, wives, and mothers quickly raged beyond domestic fire walls.

Friedan's reputation as an intellectual may have been burned in the heat of the times. Yet, in remembering her, no one should suppose Betty Friedan was a lightweight. On the contrary, after leaving Smith College she did a year of graduate study in psychology at Berkeley. She was in her own word "brilliant" at academic work, but it satisfied her little. She left schooling for the career in journalism that led to her famous book and for the marriage and family life that would supply the book its fresh authority. Feminine Mystique's chapter on "The Sexual Solipsism of Sigmund Freud" is an incisive exposé of the way Freud's narrow theories of sexual differences had putrefied postwar thinking on woman's place in the home. It would be 1970 before Kate Millett's Sexual Politics would take up the line Friedan had set down in 1963 - and still a while longer, well into the 1980s, before American feminists would begin to read Lacan to rethink Freud's ridiculous theory of feminine sexual envy. Not even the one truly great book to have 
preceded Feminine Mystique in the postwar era would tackle Freud as well as Friedan had.

That other book was, of course, Simone de Beauvoir's Second Sex, which appeared in English in 1952, well after Friedan had left graduate studies in psychology. Not even Beauvoir, who certainly understood Freud very well, went to the heart of his mistakes. Like Millett, Beauvoir's contentions were based more on literary than scientific sources. One must go back very far indeed-perhaps all the way to Charlotte Perkins Gilman's Women and Economics in 1898 - to find so robust a social-psychology of the structured plight of women of the white middle classes.

Just the same, Friedan and Beauvoir will forever be linked in the collective memory of those days. They were, though very different kinds of public intellectuals, points of reckoning for a rethinking of woman's position in the scheme of social and cultural things. Second Sex was, by far, the more complete philosophical critique. Against it, Feminine Mystique will always appear the more dated and flimsy. Still, Simone de Beauvoir, when asked many years later about the role of her book in the subsequent feminist movement, said without a hint of false modesty that she thought it had no influence whatsoever. Friedan, by contrast, may not have written the more enduring book, but her political force would linger as a clear and certain factor in feminist politics in the United States. In this respect, Friedan was the public intellectual more in keeping with political troubles that predominate in our time.

Yet, in quite another way, Friedan and Beauvoir are bound together in the changing history of feminist thought and practice. They were at the center of political and cultural movements that held the stage at a crucial moment of global change. As a consequence, they were also members of a generation of feminist thinkers now coming to the end of its time. Beauvoir (1908-1986) died near her eightieth year exactly twenty years before Friedan's death. She was almost a generation older than Friedan who was born in 1921. Yet, the two were giants of the same moment. Their great works appeared at either end of the two decades following World War Two. It was a time when, briefly, the cultural differences between North America and Western Europe were most striking. The United States throve in those decades on the industrial spoils of its brilliant success in the war. Europe was more sober for the visible fact of the material devastations upon which it would have to rebuild. The differences in social and economic prospects in those days may well have led to the illusion, long professed by the Americans, of an unbridgeable cultural divide between the two sides of Atlantic power. The Americans believed that victory was still another proof positive of their exceptional virtue. The Europeans, who never thought this way, at least not as Americans have since the 1840s, had to probe deeper into the reasons for their own deferrals and collapses before the Nazi evil.

The French theorist was beyond neglecting the long history and deep structure of, in the word she helped popularize, the othering of women. One of the most powerful passages in Second Sex is in the early section where Beauvoir, drawing equally on Levinas and Lévi-Strauss, bolsters her exposition of woman as other by identifying her with other others: "'The eternal feminine' corresponds to 'the black soul,' and to 'the Jewish character'." A small gesture perhaps - save for the ferocity of her politics in which she stood firm with all those groups oppressed by the European ideal of universal man. This was 1949. Levinas was barely read, even in France. Lévi-Strauss was just publishing the early essays of his structural anthropology. Yet, in a book that would eventually be read by many who would never read Heidegger much less Jakobson, Beauvoir wrote lines that would resonate for decades to come. The idea of othering would effectively have to await the movement that encouraged the reading of Lacan's theory of the Unconscious as the discourse of the Other.

That movement was, of course, third wave feminism which arose on the allowances of the second wave. As early standpoint feminism was decidedly second-wave, so the third wave of queer and analytically unstable categories was an elaboration of the theoretical space opened by the second wave's definition of woman's subject position. Beauvoir's book was, thus, a decidedly second-wave book, rooted in the European post-war experience. It may or may not have led to the third-wave theories associated with Julia Kristeva and Luce Irigaray in France and Judith Butler and Donna Haraway in the United States. But it was a harbinger. As was Friedan's Feminine Mystique. Not enough credit is given the harbinger. The robin's return does not cause flowers to bloom. But it allows the winter weary to keep an eye open for the bursts of yellow and green.

There was once a controversy among feminists as to whether Friedan had stolen her ideas from Beauvoir. For a long while I tracked the debate. Then I lost interest long enough that when, later, I tried to find what became of it, nothing was to be found - at least not by the usual electronic methods. The whole thing was ludicrous-some late second-waver fighting for tenure no doubt. No one who had read both books could possibly accuse Friedan of such a thing. Plus which, in her refusal to claim influence over the women's liberation movement, Beauvoir remarked correctly that though Kate Millett made no mention of her Friedan did. The famous dedication of Feminine Mystique to Simone de Beauvoir could have been made only by one who was anything but guilty over her public debt to Beauvoir. Yet, Friedan's acknowledgement of Beauvoir was made as it should have been. It was not an intellectual 
but a political and historical debt she noted.

Now that both are gone, there remain few from the second wave of feminists who continue that earlier way of thinking; and some of those who remain are bitter for the losses their hard work caused them in the coin of the academic real: recognition. Judith Butler irritates the hell out of some; perhaps rightly so. It is not at all fair that women who did the hard work of fighting the embedded patriarchy that once uniformly governed the academy not to be honored for their labors. Butler's Gender Trouble (1990) is one of the all-time best-sellers of feminist social theory. Its author wrote it out of her own considerable genius. But it could not have been received as it has been without the generations of younger thinkers who benefited from the teaching of older feminists who taught, as they fought, for a seat at the table of academic legitimacy. Butler and Irigaray are to be sure sui generis, but they would not be forces unto themselves without readers and there would not have been readers without Friedan and Beauvoir-or their functional equivalents.

From all indications Betty Friedan was not, in the word of an earlier day, a "nice" person. She was tough and rough, which was a key to her political success. She was-like few others, others of many different political dispositions-determined to see what she saw and do as she did. We look back and see, in the continuing work of NOW and so many other movements and institutions, that she was strangely prescient as well as firm in her purposes.

I met Betty Friedan but once, in passing. It was a late winter Friday afternoon in a town in the Hamptons before the jitney would bring the hordes. I was with the then new love of my life, now my wife, at a time when, as she put it, our relation was very wet. We went to the movies, if only for relief from the excitement. The film on view was Madonna's Truth or Dare-a kind of self-tribute to the one who in 1991 was clearly the very embodiment of thirdwave feminism. It was the first hour of the first day of the film's national release. There were three people in the theater. The third was Betty Friedan. I mumbled something as we came across her on leaving. The remarkable fact of it all was that the icon of second-wave feminism was so eager to hear and see the story of the icon of third-wave feminism. Like Beauvoir, Friedan embraced what would come, including that which would not come from her.

In the retrospect, as my generation of social theorists make ready to leave the scene to join those already gone, the generosity of these two harbingers reminds of the eternal return of the springtime of ideas and action. In the 2000 s - the winter of our lives and, it would seem, of the age of honest values - the robins matter a lot. They are the life that foreshadows new life-needed now more than ever. The groundhogs are cowards seeking a hole in the earth. The birds brave the chill to signify what can and will be. 